\title{
Chapter \#6
}

\section{INTERPERSONAL RELATIONS IN A CROSS-CULTURAL TEAM}

Konstantinov Vsevolod ${ }^{1}$, Shumilkina Evgeniia ${ }^{2}$, \& Osin Roman $^{3}$

${ }^{1}$ Department of General Psychology, Penza State University, Russia

${ }^{2}$ Research department, Penza State University, Russia

${ }^{3}$ Department of General Psychology, Penza State University, Russia

\begin{abstract}
In the conditions of fragility of building interethnic relations, turning to the problem of developing interpersonal relations in mono-cultural and multi-cultural teams of employees of an enterprise in the period of reorganization is extremely relevant. The article presents the results of the empirical research conducted by the authors, the conclusions were made after processing data using mathematical statistics methods. The analysis of the obtained empirical data shows that in the period of reorganization the factor of cross-cultural composition of the employees teams under study actively manifests itself in interpersonal relations. Differences were found in the level of certain characteristics of employees in different types of ethnic environments. In general, more statistically significant connections between personal and behavioral characteristics were found in the sample of employees in a multi-ethnic environment compared to the employees in a mono-ethnic environment. The development of interpersonal interaction in a team of employees in a multi-ethnic environment in the period of reorganization should be based on the development of the most significant characteristics of their personality and behavior: positive ethnic identity, empathy, interpersonal trust and skills and abilities of building interpersonal interaction.
\end{abstract}

Keywords: interpersonal relationships, cross-cultural communication, multi-ethnic environment, quality of relationships at work, labor collectives, interethnic relations.

\section{INTRODUCTION}

At present the issues of cross-cultural management and intercultural communications are becoming more and more relevant: business and intercultural relations are expanding, multinational teams are being formed. Among the theories that describe the essence of cultural differences and explain their impact on organizational behavior, the following concepts are distinguished: Values Orientation Theory (Kluckhohn \& Strodtbeck, 1961); Context of Culture (Hall \& Hall, 1990); Cultural Dimensions Theory (Hofstede, Hofstede, \& Minkov, 2010; Konstantinov, 2017). Differences between cultures in the attitude to the world were empirically confirmed. There are individualistic (competitive relations and each worker's values are at the heart of management) and collectivist (hierarchically built models of management, values of the team are more important) cultures (Bono \& Yoon, 2012; Ryzhova, Konstantinov, Gritsenko, \& Khukhlaev, 2018; Khukhlaev et al., 2019; Konstantinov \& Kovaleva, 2013).

In scientific literature there are different interpretations of the concept of "cross-culture": interaction, communication between representatives of different cultures, "intersection of cultures of different nationalities", communication and cooperation, "at the intersection of cultures", "at the clash of cultures." This variety of definitions is evidence of the complexity of the research problem. The basic axioms of cross-cultural interaction are 
the following: the absence of "bad" cultures; culture is learned by comparison; different but equal cultures meet (Vasilenko, 2013).

At first, in the 1970s the world smaller countries (Finland, Denmark, Sweden, and the Netherlands) started to study the problems of cross-cultural differences in international business. Later these countries were joined by the leading world powers (Germany, Great Britain, the USA), and later on by Italy, Spain, and France.

R. Lewis emphasizes the fact that as in the context of globalization modern business requires both great knowledge and good relationships, it is necessary to take into account cross-cultural aspects (Lewis, 2000). At the same time, problems in intercultural communication arise not because of the difficulties of communication, but because of the differences of individuals.

The quality of interpersonal relationships determines the way employees behave both at work and in personal life (Allen \& Eby, 2012; Dutton, 2014). Typically, high-quality relationships lead, among other things, to their commitment, productivity, motivation, innovation, error detection, favorable employee behavior, teamwork, helping others, effective internal and external organizational communication, avoiding conflicts, and resistance to negative events. Conversely, poor employee relationships have a detrimental impact on these aspects of the organization (Bono \& Yoon, 2012; Ryzhova et al., 2018; Khukhlaev et al., 2019; Konstantinov \& Kovaleva, 2013).

Within the framework of the personnel management system, two approaches to the management of cross-cultural groups are distinguished: "freedom from culture" and "dependence on culture". The first approach argues that human resource management is less dependent on the culture of the country than on the size of the company, the industrial environment and the production technology used. The adherents of the second approach focus on different cultural conditions in different societies, which form specific relatively stable models of thinking and behavior. These cultural circumstances influence the use of structures and leadership styles that are consistent with the existing cultural forces in society (Dikhtyar, 2012).

As a result of the intersection of different cultures, negative (conflicts) and positive (mutual cultural enrichment, new discoveries, interesting ideas, useful knowledge) consequences are possible. The influence of cultural differences is often latent. Therefore, they can be detected by interaction and comparison (Vasilenko, 2013).

Cross-cultural management is designed not only to manage cultural differences, but also to form the skills of managing culture shock (difficulties in entering a new culture when interacting with representatives of other business cultures; "a person's response to new cultural conditions of life, a certain psychological disorientation" (Soltitskaya, 2002, p. 65).

Cross-cultural teams are groups formed from representatives of different cultures with the aim of performing common tasks. In contrast to monocultural teams, they are characterized by the predominance of different cultures, mixed languages of communication and styles of interpersonal interaction. Accordingly, in order to ensure the work effectiveness of such a team, one should understand the degree of influence of the key distinctive features of each unit of the group on the work of the team as a whole. In cross-cultural teams, two scenarios for the development of relations within a group are possible: the establishment of cultural unity and cohesion, or subgroup dominance and the effect of exclusion from intragroup interaction (Vedernikova, 2017). In the field of team architecture, the following three most important factors for the inclusion of an individual in a multicultural team dominate: professional qualities, the ability to work in a team, respect, and tolerance. Leaders of cross-cultural teams, as well as their members, can solve these 
problems in different ways based on their cultural affiliation, which determines the specifics of their approaches and team management strategies (Zenchenko, 2016). Representatives of different business cultures in cross-cultural groups have different motives, incentives, rules, norms, traditions, communication styles, and can also perceive work situations in different ways (Zenchenko, 2016). Research in the field of managing cross-cultural groups proves that "difficulties arise in the communication of representatives of different cultures due to the national characteristics of their communicative behavior, which is defined as verbal and non-verbal behavior, people, individuals, groups of people in the process of communication, regulated by norms and traditions of communication in this society" (Grishaeva, 2009). It seems that in the subject of cross-cultural studies, the problem of social and cultural distance (the measure of the similarity and difference in social positions, elements of culture in specific conditions) acquires a special meaning. The closer the values and basic attitudes of cultures, the less the cultural distance and, accordingly, the easier it is to build relationships in a cross-cultural community. The main factors for the effectiveness of a cross-cultural team are tolerance, empathy, knowledge of other cultures, foreign languages.

G. A. Soltitskaya identifies a number of problems of intercultural communication in organizations: first, the belonging of the team members to different cultures, secondly, different verbal / non-verbal interpretation, and thirdly, "fitting" into different contexts. Each culture has its own model of ideal communication, which is consciously / unconsciously realized during communication (Soltitskaya, 2002). Culture also determines the choice of the communication form (oral or written). So, for example, some cultures gravitate more towards written speech (England), others towards oral speech (Russia), and still others towards their combination (Thailand). The selection of specific words is also very important, since they have different connotations in different cultures (Soltitskaya, 2002). Cross-cultural competence is closely related to cross-cultural communication (Myasoedov \& Borisova, 2015). In scientific literature, there are different variations in the understanding of cross-cultural competence, for example, intercultural, multicultural competence, cross-cultural literacy, etc. Cross-cultural competence is considered as an integral quality of a person (knowledge about the characteristics of other cultures, the ability to interpret foreign cultural information, experience of intercultural interaction, personal qualities: empathy, tolerance (Shakhnazarova, 2012).

Considering the specifics of managing cross-cultural teams requires addressing the cross-cultural aspects of organizational conflicts. Thus, in collectivist cultures, direct confrontation is avoided, and in individualist cultures, expressing one's opinion is an integral characteristic of an honest person. In cultures with a large power distance, conflict between levels is normal and expected. In cultures with a small power distance, harmony between the powerful and the powerless is valued, and colleagues tend to cooperate (Soltitskaya, 2002). Cultural differences influence the choice of strategy and tactics for resolving organizational conflicts. In masculine cultures, conflict is resolved through struggle, in feminine cultures, through negotiation and compromise. In English-speaking cultures, the desire for confrontation is prized. The Japanese and Chinese seek to resolve conflicts through compromise and consensus. The cultural factor influences the choice of an action strategy in a conflict situation. Thus, in cultures with a large power distance, the leader prefers not to intervene in the conflict. Arbitration is valued in collectivist cultures (Soltitskaya, 2002). Among the main causes of cross-cultural conflicts, the following should be highlighted: inconsistency and consistency of legal and institutional norms governing relations in different countries; factors of cross-cultural communication; interpersonal conflicts (Ma \& Maksimova, 2018). 
Perceptions of the degree to which an organization provides its employees with appropriate, fair and respectful treatment, adequate and accurate information, resources and rewards are conceptualized as perceptions of organizational justice (Bell, Wiechmann, \& Ryan, 2006; Chernyak-Hai \& Tziner, 2012; Cropanzano, Prehar, \& Chen, 2002; Tyler \& Bies, 1990). Employees establish their perceptions of organizational justice through (1) overall impressions that are a consequence of random organizational occurrences and (2) personal evaluations based on specific "organizational components," such as leaders and co-workers (Hollensbe, Khazanchi, \& Masterson, 2008). Perceptions of organizational justice may be broken down into perceptions of distributive justice (fairness in resources and products allocation), procedural justice (fairness of organizational procedures and ways in which decisions are reached vis-à-vis the distribution of resources), and interactional justice (fairness of organizational inter-personal relations and accessibility of equal opportunities) (Kernan \& Hanges, 2002; Miller \& Lee, 2001; Tang \& Sarsfield-Baldwin, 1996). Previous research has pointed to positive associations between perceptions of organizational justice and organizational citizenship behavior (employees' actions defined as behaviors that benefit the organization by contributing to its environment and beyond formal job) (Chernyak-Hai \& Tziner, 2012; Organ, Podsakoff, \& MacKenzie, 2006; Podsakoff, MacKenzie, Paine, \& Bachrach, 2000; Rotundo \& Sackett, 2002), overall high job motivation and satisfaction (Hubbell \& Chory-Assad, 2005; Latham \& Pinder, 2005), trust, commitment, and productivity (Karriker \& Williams, 2009), and loyalty and readiness to accept organizational consequences (Joy \& Witt, 1992).

Organizational climate is defined as the social climate or atmosphere in a workplace relevant to policies, practices, and procedures in organizations (see Schneider, 2000; Schulte, Ostroff, \& Kinicki, 2006, Park, Lee, Park, Lee \& Lee, 2019; Fernández-Salinero, Navarro \& Topa, 2019). Perceptions of organizational climate are part of an active psychological process that helps employees recognize what behaviors are expected and rewarded (Armstrong, 2003; Zohar \& Luria, 2005). These perceptions not only reflect employees' impressions of the work environment, they also influence their levels of stress, job satisfaction, commitment, and performance which, in turn, have implications for overall organizational productivity (Ostroff, Kinicki, \& Tamkins, 2003; Schulte et al., 2006). Measures used to investigate perceptions of organizational climate are similar, in many ways, to those used to investigate perceptions of "organizational culture", insofar as they are measures of what has been termed the "deep structure of organizations" (e.g., Reichers \& Schneider, 1990; Payne, 2000; May, 2020). Although at face value, perceived organizational climate may be seen as a mainly cognitively acquired attitude, it should be noted that significant evaluative and affective components are reflected in employees' perceptions of organizational values and processes (Patterson, Warr, \& West, 2004), such that both intellectual and emotional factors impinge on employee job behavior and social interactions at the workplace (Schneider, 2000). And with respect to social action, it has been proposed that employee attitudes and behaviors are not only influenced by perceptions of organizational climate but also by the perceptions of co-workers (Mathieu \& Kohler, 1990; Erkmen, Günsel \& Altındağ, 2020).

Instrumental climate is considered a negative type of climate as it focuses on self-interest, while the other types of ethical climate are considered to be positive, insofar as they promote the emergence of positive organizational attitudes following concern for the well-being of others, for laws or organizational policies and procedures to be followed, and adherence to one's personal ethical beliefs (Leung, 2007; Martin \& Cullen, 2006; Wimbush, Shepard, \& Markham, 1997). The ethical climate provides cues to employees as to the behavior that is appropriate in a certain work environment. Specifically, employees are 
supposed to be less likely to exhibit unethical behaviors if the ethical climate emphasizes ethical behaviors (Mayer, Kuenzi, \& Greenbaum, 2010). Previous research has shown support for the notion that an ethical work climate is associated with unethical organizational behaviors. Results of a meta-analysis (Martin \& Cullen, 2006) indicated that positive ethical climates are negatively related to organizational behavior. It was found that organizational deviance is lower in ethical caring climates (Mayer et al., 2010).

The level of efficiency and development of an organization is largely determined by the ability of employees to interact and cooperate with each other, which can be traced in a cross-cultural context.

The impact of the ethno-cultural factor, which leads to the formation of a special environment for building interpersonal relations, was studied by a number of domestic and foreign psychologists. But the data on the influence of ethnic characteristics of individuals on their interpersonal relationships are insufficient to build a holistic view of this process (Berry, Galyapina, Lebedeva, Lepshokova, \& Ryabichenko, 2019; Grigoryev, van de Vijver, \& Batkhina, 2018; Khukhlaev, Kuznetsov, \& Chibisova, 2013; Raman, Sambasivan, \& Kumar, 2016).

Interpersonal relationships are subjectively experienced relationships between people, mutually influencing each other in the process of cooperation and communication. They differ in a number of parameters: their origin, stability, duration, openness of the parties, etc. The process of initiating, maintaining and terminating interpersonal relationships is determined by a number of factors. These include individual psychological and typological features of the interpersonal interaction, as well as the conditions for this interpersonal interaction.

The ethnic factor is an important factor for maintaining efficient interpersonal relations. Researchers note that the ethnic environment includes many modifications of the surrounding reality, accumulated by members of the ethnic community in the course of its historical development. The ethnic factor sets the context for interpersonal relations, determines the behavioral patterns of their individuals and the readiness to maintain relations with a member of another ethnic group. At the personal level, ethnicity is manifested at the level of the person's ethnic identity, ethnic self-consciousness, the ability to acquire ethnic attitudes, stereotypes, prejudices, etc.

\section{SAMPLING, TECHNIQUES AND METHODS OF THE RESEARCH}

426 employees (from 18 to 56 years of age) of enterprises of the Penza region and the Republic of Mordovia participated in our empirical study. We assumed that interpersonal relationships of employees in the period of reorganization are a complex phenomenon determined by the ethnotype of the working environment and characterized by a number of features that influence their qualitative and quantitative parameters.

Verification of the proposed hypotheses was carried out by solving a number of theoretical, methodological and empirical problems. The empirical study aimed at comparing the distribution of status positions among members in mono- and multi-ethnic groups, identifying the level of conflict in their relations, studying the examples of the phenomena of empathy and trust in mono - and multi-ethnic environment, establishing the type of the relationship between ethnic identity and response/feedback strategies in conflict situations (compromise, cooperation).

In the course of the study, the following methods and techniques were used: "The Interpersonal Trust Scale" by J. B. Rotter, "The technique of empathic abilities diagnosis" by V. V. Boyko, "Types of ethnic identity" by G. U. Soldatova, "The level of conflict" by 
A. M. Ganeev and L. S. Tronova, "The features of handling conflict styles" by C. Thomas. To process the results of the study, mathematical procedures of indicators and statistical data reliability assessment were used (Raygorodsky, 2017; Tatarko \& Lebedeva, 2011).

\section{THE RESEARCH RESULTS, THEIR DISCUSSION}

In the course of the empirical study, it was found that employees of mono-ethnic professional environments are much more likely $(\mathrm{p}<0.01)$ to come into contact with each other than workers of multi-ethnic professional environments. Contacts of people belonging to different ethnic groups are usually limited to issues connected with business or job responsibilities.

Workers in mono-ethnic environments maintain interpersonal contacts for a longer period than workers in multi-ethnic environments $(p<0.05)$. Interpersonal relations of workers in mono-ethnic groups are more dynamic by nature and prolonged in time. Considerable length of interpersonal contacts in mono-ethnic environments is caused by numerous reasons and grounds to establish and maintain such relationships, by greater interest in each other, their desire to communicate, and their openness to interaction.

There is a difference in the modality of interpersonal relationships between the workers of the two samples (at a statistically reliable level of $\mathrm{p}<0.01$ ). Workers from a mono-ethnic professional environment show more enthusiasm than workers in multi-ethnic environments. These observations indicate that in multi-ethnic environments there is certain tension and reticence in contacts and interpersonal relations between employees of different ethnic groups. At the same time, they are more sensitive to issues concerning ethnicity and ethnic background, so they are more likely to engage in conflict with each other.

The percentage of workers with the average status in mono- and multi-ethnic environments is approximately the same (75.9\% and $70.4 \%$, respectively). Differences were found in the percentage of workers with high and low sociometric status depending on the environment they belong to. The percentage of high status workers in mono- and multi-ethnic professional environments was $19.1 \%$ and $11.7 \%$ respectively $(\mathrm{p}<0.05)$. More fundamental differences were found in the subsamples of workers with low sociometric status in mono- and multi-ethnic environments $(5.0 \%$ and $17.9 \%$ respectively). The percentage difference is characterized by statistical significance $(\mathrm{p}<0.01)$, i.e. in multi-ethnic environments the proportion/percentage of workers with low sociometric status is much higher than in mono-ethnic environments.

In mono-ethnic groups the number of workers with a low level of conflict exceeds $(18.1 \%)$ the proportion of such workers in multi-ethnic environments $(13.1 \%)$. The same trend is observed with the percentage of workers who are characterized by an average level of conflict: there are slightly more of them in mono-ethnic groups $(68.2 \%)$ than in multi-ethnic groups $(61.9 \%)$. The level of statistical significance $p<0.05$, indicating certain differences between the compared samples, does not allow us to note their stability.

According to the results, workers in multi-ethnic professional environments show a higher level of conflict than workers in mono-ethnic environments. The reason is that the multi-ethnic environment requires the workers to meet additional challenges, e.g. choosing life priorities. In contrast to workers from mono-ethnic environments, who are faced only with the task of personal self-assertion, professional and life choices, workers from multi-ethnic environments need to self-identify in their own ethnic environment, to correlate their personal, professional, and life priorities with ethnic attitudes, norms, and customs. At the same time, they have to interact with representatives of other ethnic groups, with an ethnically different culture, attitudes and customs. The complexity and diversity of 
the tasks, which workers from multi-ethnic environments are faced with, create tension, make them more aggressive and contentious in interpersonal interaction. To the greatest extent, it is this kind of behavior that is used with people belonging to other ethnic groups.

Workers from mono-and multi-ethnic environments have statistically significant differences $(\mathrm{p}<0.01)$ in the degree of manifestation of the high and low levels of interpersonal trust. In the sub-samples of workers, there was a significant excess of the number of employees with a high level of interpersonal trust (the average value is $27.0 \%$ ) over the number of employees with a low level of interpersonal trust $(14.0 \%)$. In sub-samples of workers in multi-ethnic environments, a statistically significant excess of the number of employees with a low level of interpersonal trust $(27.6 \%)$ over the number of employees with a high level of interpersonal trust (13.3\%) was found. In the sample of workers working in a mono-ethnic environment, the average value of interpersonal trust is 6.5 units, in the sample of workers in a multi-ethnic environment it is 4.3 units. The obtained discrepancy in the quantity of manifestation of the trait indicates statistically significant differences in its manifestation in workers, depending on what environment (mono- or multi-ethnic) the employee belongs to. In a multi-ethnic environment, interpersonal trust between workers is much less manifested than among workers working in a mono-ethnic environment.

In the sample of workers from a multi-ethnic environment, there tends to be more workers with a low level of empathy. However, the differences in the level of empathy were somewhat more smoothed, not so vividly manifested. This can be explained by the specific functioning of the phenomena under consideration. It is obvious that empathy has more opportunities for its development, regardless of the ethnic and national characteristics of the people around. Trust is based on knowledge of a wider range of background information that characterizes the subject of potential interaction. Accordingly, it may be easier for a person to show empathy than interpersonal trust. At the same time, it is interpersonal trust that has the greatest influence on the quality and intensity of building interpersonal relationships in the environment.

In multi-ethnic environments in all sub-samples tested by the "Types of ethnic identity" by G. U. Soldatova, the proportion of workers characterized by ethno-egoism, which can be expressed either in a harmless form or by a very aggressive behavior, predominates. In the first case, the perception of the surrounding world through the semantic prism of "my people" comes first. In the second case, employees demonstrate sufficient tension/aggression in interpersonal relationships with people belonging to other ethnic groups. It can be supposed the high level of conflict and low levels of empathy and interpersonal trust in multi-ethnic environments is caused by the dominance of this type of ethnic identity.

Studying the types of response to a conflict situation allowed us to find out that in the samples of workers in mono-ethnic environments, cooperation is the most widely-used strategy of behavior in conflict situations $(27.5 \%)$. This type of behavior manifests itself in adopting the decision that fully satisfies the interests of both parties to the conflict. Trying to achieve a compromise is another type of widespread behavior in a conflict of employees in a mono-ethnic environment $(23.6 \%)$. The behavior of employees who follow this pattern of behavior is manifested in the establishment of an agreement between the parties to the conflict. Competition/rivalry is another form of behavior in a conflict situation $(22.2 \%)$. This type of behavior in a conflict situation is manifested in the desire of workers to forward their own interests at the expense of the interests of the partners in interpersonal interaction. In the samples of workers under study adaptation $(14.4 \%)$ and avoidance 
behavior $(12.3 \%)$ come next. These strategies of behavior in a conflict situation are chosen by approximately $10 \%$ of the entire sample of employees in a mono-ethnic environment.

In the sample of workers in multi-ethnic environments other behavioral preferences in conflict situations were detected. However, we note that the preferred behavioral patterns in the sample of employees were distributed more evenly in this group. The evident type of behavior in the sample of workers in a multi-ethnic environment was avoidance behavior $(23.8 \%)$. Accordingly, we can say that approximately $25 \%$ of the employees, in this case, are focused on avoiding a conflict situation. At the same time, they do not demonstrate the desire to ensure cooperation with the subject of interaction and are not focused on achieving any of their own goals in a conflict situation. Approximately the same percentage of employees in the sample of employees in a multi-ethnic environment was focused on the strategy of competition in a conflict situation (23.1\%). This type of behavior, associated with the desire to achieve the satisfaction of their interests at the expense of the interests of the partner in interpersonal relations, was demonstrated by about a quarter of all employees in a multi-ethnic environment. In a multi-ethnic environment the strategy of adaptation to the current situation was mostly expressed. This type of behavior was chosen by $21.6 \%$ of workers, i.e. about $1 / 5$ of the entire sample. This type of behavior is characterized by sacrificing one's own interests for the sake of the interaction partner. This behavior is the opposite of rivalry/competition in a conflict situation, which is the second most commonly demonstrated behavioral pattern in this sample. The cooperation strategy (20.6\%) turned out to be significant for employees in a multi-ethnic environment. This type of behavior in a conflict situation was a priority for about $1 / 5$ of the workers in the sample. This suggests that a fairly large proportion of workers in a multi-ethnic environment are ready to accept an alternative that would fully satisfy the interests of both sides in interpersonal relations.

The most evident differences between workers in mono- and multi-ethnic environments were revealed in the two types of behavior in a conflict situation - trying to achieve a compromise and avoidance behavior. Workers who study in a mono-ethnic environment are more inclined to use the first type, while workers in a multi-ethnic environment tend to follow the second behavioral pattern. A difference in the propensity to use adaption strategy and to cooperate was revealed only as a trend. The first type of behavior (adaption) is characteristic of workers in a multi-ethnic environment, while the second (cooperation) characterizes workers in a mono-ethnic environment.

The analysis of the obtained empirical data shows that the factor of cross-cultural composition of the groups has a great impact on interpersonal relationships in their teams under study in the period of reorganization. The method of correlation analysis made it possible to establish differences in the level of intensity of interconnection of employees belonging to different types of ethnic environments. In mono-ethnic environments several trends characterizing their interpersonal relationships are observed: trust goes with a tendency to compromise ( $\mathrm{p}<0.001)$; ethnic nihilism is directly combined with conflict, on the one hand, and with a tendency to compromise, on the other hand, $(\mathrm{p}<0.01)$; ethnic nihilism goes with ethnic fanaticism (feedback) $(\mathrm{p}<0.01)$; ethnic indifference is combined with a tendency to cooperate (feedback) ( $\mathrm{p}<0.05)$; avoidance behavior is not compatible with the tendency of an individual to compete in a conflict situation of interpersonal interaction $(\mathrm{p}<0.01)$.

In the multi-ethnic environment the following relationships were observed: those between a positive ethnic identity and a tendency to cooperate (direct link) ( $<<0.01)$, as well as tendency to ethnic isolationism and conflict (feedback) ( $\mathrm{p}<0.001$ ); empathy and a person's desire to cooperate (direct link) and ethnic isolationism (feedback) $(\mathrm{p}<0.01)$; interpersonal trust and inclination to adapt (direct link) ( $\mathrm{p}<0.01)$; a tendency to 
compromise and avoidance behavior (feedback) ( $\mathrm{p}<0.05)$. The development of interpersonal interaction in a multi-ethnic environment in a team of employees in the period of reorganization should be based on the development of the most significant characteristics of their personality and behavior: positive ethnic identity, empathy, interpersonal trust and skills and abilities of building interpersonal interaction.

\section{CONCLUSIONS}

In the sample of employees of a multi-ethnic environment, the positive ethnic identity of an individual was the most informative. The great number of statistically significant connections of personality traits and types of behavior was found out. Such characteristics of employees' personality as empathy and ethnic isolation (two correlations) were also quite informative. On the whole, there are more statistically significant correlations between personal and behavioral characteristics in the sample of employees in a multi-ethnic environment than in a mono-ethnic environment. The development of interpersonal interaction in a multi-ethnic environment in teams of employees in the period of reorganization should be based on the development of the most significant characteristics of their personality and behavior: the positive ethnic identity, empathy, interpersonal trust and skills of building interpersonal interaction.

The greatest problems in intercultural communication among team members and conflicts are caused by cultural differences. The solution to these problems depends on the use of cross-cultural management strategies. In order to form an effective management system of a multinational company, the following points should be taken into account: the type of multinational company, the influence of corporate and national cultures, the dominant position of one national culture in the team over others, the necessity to acculturate new members of the organization, training managers of multinational companies to work within a different national culture, being aware of a communication code of this foreign culture (the language, customs and rules of behavior, psychology and mentality, etc.).

\section{REFERENCES}

Allen, T. D., \& Eby, L. T. d. T. (2012). The study of interpersonal relationships: An introduction. In L. T. d. T. Eby \& T. D. Allen (Eds.), SIOP organizational frontiers series. Personal relationships: The effect on employee attitudes, behavior, and well-being (pp. 3-13). Routledge/Taylor \& Francis Group.

Armstrong, M. (2003). A handbook of human resource management practice. London: Kogan Page Limited.

Bell, B. S., Wiechmann, D., \& Ryan, A. M. (2006). Consequences of organizational justice expectations in a selection system. Journal of Applied Psychology, 91(2), 455-466. doi:10.1037/0021-9010.91.2.455

Berry, J., Galyapina, V., Lebedeva, N., Lepshokova, Z., \& Ryabichenko, T. (2019). Intercultural Relations in Georgia and Tajikistan: A Post-Conflict Model. Psychology. Journal of the Higher School of Economics, 16(2), 232-249. doi:10.17323/1813-8918-2019-2-232-249

Bono, J. E., \& Yoon, D. J. (2012). Positive supervisory relationships. In L. T. d. T. Eby \& T. D. Allen (Eds.), SIOP organizational frontiers series. Personal relationships: The effect on employee attitudes, behavior, and well-being (pp. 43-66). Routledge/Taylor \& Francis Group.

Chernyak-Hai, L., \& Tziner, A. (2012). Organizational citizenship behaviors: Socio-psychological antecedents and consequences. Revue Internationale de Psychologie Sociale, 25(3-4), 53-92. 
Interpersonal Relations in a Cross-Cultural Team

Cropanzano, R., Prehar, C. A., \& Chen, P. Y. (2002). Using Social Exchange Theory to Distinguish Procedural from Interactional Justice. Group \& Organization Management, 27(3), 324-351. doi:10.1177/1059601102027003002

Dikhtyar, A. B. (2012). Kross-kul'turnye stili upravlenija personalom organizacii. [Cross-cultural styles of organization's personnel management]. Vestnik universiteta (GUU), 8, 85-88.

Dutton, J. E. (2014). Build high quality connections. In J.E. Dutton \& G.M. Spreitzer (Eds.), How to be a positive leader: Small actions big impact (pp. 11-21). San Francisco, CA: Berrett-Khoeler.

Erkmen, T., Günsel, A., \& Altındağ, E. (2020). The Role of Innovative Climate in the Relationship between Sustainable IT Capability and Firm Performance. Sustainability, 12(10), 4058. doi:10.3390/su12104058

Fernández-Salinero, S., Navarro Abal, Y., \& Topa, G. (2019). On the Relationship between Perceived Conflict and Interactional Justice Influenced by Job Satisfaction and Group Identity. Sustainability, 11(24), 7195. doi:10.3390/su11247195

Grigoryev, D., van de Vijver, F., \& Batkhina, A. (2018). Discordance of Acculturation Attitudes of the Host Population and their Dealing with Immigrants. Journal of Intercultural Communication Research, 47(6), 491-509. doi:10.1080/17475759.2018.1497678

Grishaeva, L. I. (2009). Specifika dejatel'nosti kommunikantov v mezhkul'turnoj srede [The specifics of the communicants in a cross-cultural environment]. Voronezh: Nauchnaja kniga.

Hall, E. T. \& Hall, M. R. (1990). Understanding cultural differences: Germans, French and Americans. Yarmouth, ME: Intercultural Press.

Hofstede, G. H., Hofstede, G. J., \& Minkov, M. (2010). Cultures and organizations: Software of the mind. Maidenhead: McGraw-Hill.

Hollensbe, E. C., Khazanchi, S., \& Masterson, S. S. (2008). How Do I Assess If My Supervisor and Organization are Fair? Identifying the Rules Underlying Entity-Based Justice Perceptions. The Academy of Management Journal, 51(6), 1099-1116. doi:10.5465/amj.2008.35732600

Hubbell, A. P., \& Chory-Assad, R. M. (2005). Motivating factors: perceptions of justice and their relationship with managerial and organizational trust. Communication Studies, 56(1), 47-70. doi:10.1080/0008957042000332241

Joy, V. L., \& Witt, L. A. (1992). Delay of Gratification as a Moderator of the Procedural Justice Distributive Justice Relationship. Group \& Organization Management, 17(3), 297-308. doi:10.1177/1059601192173008

Karriker, J. H., \& Williams, M. L. (2007). Organizational Justice and Organizational Citizenship Behavior: A Mediated Multifoci Model $\dagger$. Journal of Management, 35(1), 112-135. doi:10.1177/0149206307309265

Kernan, M. C., \& Hanges, P. J. (2002). Survivor reactions to reorganization: Antecedents and consequences of procedural, interpersonal, and informational justice. Journal of Applied Psychology, 87(5), 916-928. doi:10.1037/0021-9010.87.5.916

Kluckhohn, F. R. \& Strodtbeck, F. L. (1961). Variations in value orientations. Evanston, IL: Row, Peterson.

Khukhlaev, O. E., Alexandrova, E. A., Gritstnko, V. V., Konstantinov, V. V., Kuznetsov, I. M., Pavlova, O. S., ... Shorokhova, V. A. (2019). Identifikacija s religioznoj gruppoj i jetnonacional'nye ustanovki buddistskoj, musul'manskoj i pravoslavnoj molodezhi [Religious Group Identification and Ethno-National Attitudes in Buddhist, Muslim and Orthodox Youth]. Kul'turno-istoricheskaja psihologija, 15(3), 71-82. doi:10.17759/chp.2019150308

Khukhlaev, O.E., Kuznetsov, I.M., \& Chibisova M.Yu. (2013). The integration of migrants in the educational environment: social and psychological aspects. Psychological Science and Education, 18 (3), 5-17.

Konstantinov, V. \& Kovaleva, N.A. (2013). Rasstavanie s rodinoj: social'no-psihologicheskaja problema migracii. [Parting with motherland as socio-psychological problem of migration] Psihologicheskij zhurnal, 34(5), 3-15.

Konstantinov, V. (2017). The Role of the Host Local Population in the Process of Migrants Adaptation. Social Sciences, 6(3), 92. doi: 10.3390/socsci6030092 
K. Vsevolod, S. Evgeniia, \& O. Roman

Latham, G. P., \& Pinder, C. C. (2005). Work Motivation Theory and Research at the Dawn of the Twenty-First Century. Annual Review of Psychology, 56(1), 485-516. doi:10.1146/annurev.psych.55.090902.142105

Leung, A. S. M. (2007). Matching Ethical Work Climate to In-role and Extra-role Behaviors in a Collectivist Work Setting. Journal of Business Ethics, 79(1-2), 43-55. doi:10.1007/s10551-007-9392-6

Lewis, R. D. (2000). When cultures collide: managing successfully across cultures ( $2 \mathrm{rd}$ ed.). London: Nicholas Brealey Publishing.

Ma, S. \& Maksimova, S. M. (2018). Problemy v upravlenii personalom na osnove kross-kul'turnyh osobennostej v kompanii mezhdunarodnogo biznesa [Challenges in personnel management based on cross-cultural Benchmarks in an international business company]. Studencheskij: jelektronnyj nauchnyj zhurnal, 12 (32). Retrieved from: https://sibac.info/journal/student/32/111782

Martin, K. D., \& Cullen, J. B. (2006). Continuities and Extensions of Ethical Climate Theory: A Meta-Analytic Review. Journal of Business Ethics, 69(2), 175-194. doi:10.1007/s10551-006-9084-7

Mathieu, J. E., \& Kohler, S. S. (1990). A cross-level examination of group absence influences on individual absence. Journal of Applied Psychology, 75(2), 217-220. doi:10.1037/0021-9010.75.2.217

May, M. (2020). Superordinate Ties, Value Orientations, and Congregations' Organizational Cultures. Religions, 11(6), 277. doi:10.3390/rel11060277

Mayer, D. M., Kuenzi, M., \& Greenbaum, R. L. (2010). Examining the Link Between Ethical Leadership and Employee Misconduct: The Mediating Role of Ethical Climate. Journal of Business Ethics, 95(S1), 7-16. doi:10.1007/s10551-011-0794-0

Miller, D., \& Lee, J. (2001). The people make the process: commitment to employees, decision making, and performance. Journal of Management, 27(2), 163-189. doi:10.1177/014920630102700203

Myasoedov, S. P. \& Borisova, L. G. (2015). Kross-kul'turnyj menedzhment [Cross-cultural management]. Moscow, Russia: Yurayt.

Ostroff, C., Kinicki, A. J., \& Tamkins, M. M. (2003). Organizational culture and climate In: W. C. Borman, D. R. Ilgen, \& R. J. Klimoski (Eds.), Handbook of psychology: Industrial and organizational psychology (Vol. 12, pp. 565-593). Hoboken, NJ: Wiley. doi:10.1002/0471264385.wei1222

Organ, D. W., Podsakoff, P. M., \& MacKenzie, S. B. (2006). Organizational citizenship behavior: Its nature, antecedents, and consequences. Thousand Oaks, CA: Sage. doi:10.4135/9781452231082

Park, H., Lee, K.-S., Park, Y.-J., Lee, D.-J., \& Lee, H.-K. (2019). The Association between Organizational Justice and Psychological Well-Being by Regular Exercise in Korean Employees. International Journal of Environmental Research and Public Health, 16(12), 2223. doi:10.3390/ijerph16122223

Patterson, M., Warr, P., \& West, M. (2004). Organizational climate and company productivity: The role of employee affect and employee level. Journal of Occupational and Organizational Psychology, 77(2), 193-216. doi:10.1348/096317904774202144

Payne, R. L. (2000). Climate and culture: how close can they get? In N. M. Ashkanasy, C. P. M Wilderom, \& M. F. Peterson (Eds.), Handbook of organizational culture and climate (pp. 163-176). Thousand Oaks, CA: Sage Publications, Inc.

Podsakoff, P. M., MacKenzie, S. B., Paine, J. B., \& Bachrach, D. G. (2000). Organizational Citizenship Behaviors: A Critical Review of the Theoretical and Empirical Literature and Suggestions for Future Research. Journal of Management, 26(3), 513-563. doi:10.1177/014920630002600307

Raman, P., Sambasivan, M., \& Kumar, N. (2016). Counterproductive work behavior among frontline government employees: Role of personality, emotional intelligence, affectivity, emotional labor, and emotional exhaustion. Revista de Psicología del Trabajo y de las Organizaciones, 32(1), 25-37. doi:10.1016/j.rpto.2015.11.002. 
Raygorodsky, D.Ya. (2017). Prakticheskaja psihodiagnostika. Metodiki i testy [Practical psychodiagnostics. Methods and tests]. Samara, Russia: Bakhrakh-M.

Reichers, A. E., \& Schneider, B. (1990). Climate and culture: An evolution of constructs. In: B. Schneider (Ed.), Organizational climate and culture (pp. 5-39). San Francisco: Jossey-Bass.

Rotundo, M., \& Sackett, P. R. (2002). The relative importance of task, citizenship, and counterproductive performance to global ratings of job performance: A policy-capturing approach. Journal of Applied Psychology, 87(1), 66-80. doi:10.1037/0021-9010.87.1.66

Ryzhova S., Konstantinov V., Gritsenko V. \& Khukhlaev O. (2018). Struktura religioznoj identichnosti sovremennoj pravoslavnoj molodezhi. [Structure of religious identity of modern orthodox youth]. Psihologicheskij zhurnal, 39(4), 95-104. doi:10.31857/S020595920000074-7

Shakhnazarova, A. A. (2012). Kriterii sformirovannosti kross-kul'turnoj kompetentnosti shkol'nikov. [Criteria for the formation of cross-cultural competence schoolchildren]. Vestnik RUDN, 3, 193-199.

Schneider, B. (2000). The psychological life of organizations. In N. M. Ashkanasy, C. P. M. Wilderon, \& M. F. Peterson (Eds.), Handbook of organizational culture and climate (pp. xvii-xxi). Thousand Oaks, CA: Sage.

Schulte, M., Ostroff, C. \& Kinicki, A. J. (2006). Organizational climate systems and psychological climate perceptions: A cross-level study of climate-satisfaction relationships. Journal of Occupational and Organizational Psychology, 79(4), 645-671. doi: 10.1348/096317905x72119

Soltitskaya, G. A. (2002). Kross-kul'turnye aspekty upravlenija personalom [Cross-cultural aspects of HR management]. Vestnik Sankt-Peterburgskogo universiteta, 4, 51-70.

Tang, T. L., \& Sarsfield-Baldwin, L. J. (1996). Distributive and procedural justice as related to satisfaction and commitment. SAM Advanced Management Journal, 61, 25-31.

Tatarko, A., \& Lebedeva, N. (2011). Metody jetnicheskoj i krosskul'turnoj psihologii [Methods of ethnic and cross-cultural psychology]. Moscow, Russia: Izdatel'skij dom NIU VShJe. doi:10.17323/978-5-7598-0867-1

Tyler, T. R., \& Bies, R. J. (1990). Beyond formal procedures: The interpersonal context of procedural justice. In J. Carroll (Ed.), Applied Social Psychology and Organizational Settings (pp. 77-98). Hillsdale, NJ: Lawrence Erlbaum Associates. doi:10.4324/9781315728377-4

Vasilenko, N. G. (2013). Razvitie kross-kul'turnogo menedzhmenta [Development of cross-cultural management]. Al'manah sovremennoj nauki i obrazovanija, 2(69), 48-50.

Vedernikova, E. Yu. (2017). Jeffektivnoe upravlenie kross-kul'turnymi komandami. Raspredelenie komandnyh rolej v TNK [Effective cross-cultural team management. Distribution of command roles in TNCs]. In N.N. Ponarin \& S.S. Chernov, Innovacionnye tehnologii v sovremennyh nauchnyh issledovanijah: jekonomicheskie, social'nye, filosofskie, politicheskie, pravovye, obshhenauchnye tendencii: materialy konferencii (pp. 51-53). Saratov, Russia: Akademija upravlenija.

Wimbush, J. C., Shepard, J. M., \& Markham, S. E. (1997). An empirical examination of the relationship between ethical climate and ethical behavior from multiple levels of analysis. Journal of Business Ethics, 16, 1705-1716. doi: 10.1023/A:1017952221572

Zenchenko, N. P. (2016). Upravlenie kross-kul'turnymi kollektivami v organizacijah [Management of cross-cultural groups in organizations] (Doctoral dissertation, Plekhanov Russian University of Economics, Moscow, Russian Federation). Retrieved from http://ords.rea.ru/wpcontent/uploads/2016/12/Zenchenko.pdf

Zohar, D., \& Luria, G. (2005). A Multilevel Model of Safety Climate: Cross-Level Relationships Between Organization and Group-Level Climates. Journal of Applied Psychology, 90(4), 616-628. doi:10.1037/0021-9010.90.4.616 


\section{ACKNOWLEDGEMENTS}

Author Contributions: (V.K.) Vsevolod Konstantinov and (E.Sh.) Evgeniia Shumilkina conducted the empirical part of the research as well as analyzed and described the received data. (R.O.) Roman Osin provided significant assistance in interpreting the results and presenting them in the written form. All the above mentioned authors have made a considerable contribution to this work.

The study was conducted according to the American Psychological Association's (APA) ethical principles of psychologists and code of conduct.

Conflicts of Interest: The authors declare no conflict of interest.

\section{AUTHORS' INFORMATION}

Full name: Vsevolod Konstantinov

Institutional affiliation: Penza State University

Institutional address: Krasnaya Street, 40, Penza, 440026, Russia

Short biographical sketch: Doctor of Psychology, Professor, Head of the Department of General Psychology. Vsevolod V. Konstantinov graduated from the Faculty of Psychology and Social Work of Penza State Pedagogical University named after V.G. Belinsky in 1999. In 2004, V. Konstantinov defended his thesis on the topic "Dependence of the success of the socio-psychological adaptation of forced migrants to new living conditions on the type of residence". In 2018, he defended his thesis for the degree of Doctor of Psychological Sciences on the topic "Socio-psychological adaptation of migrants in a host multicultural society." V. Konstantinov is the editor-in-chief of the electronic scientific journal Penza Psychological Newsletter. V. Konstantinov is a member of the reviewer board of the journal Behavioral Sciences. Under the scientific supervision of V. Konstantinov, nine theses for the degree of candidate of psychological sciences have been defended.

Full name: Evgeniia Shumilkina

Institutional affiliation: Penza State University

Institutional address: Krasnaya Street, 40, Penza, 440026, Russia

Short biographical sketch: Evgeniia Shumilkina is a head of research department of Penza State University and attached to Saratov State University to write the thesis. Her current research focuses on specifics of interpersonal relations in poly- and mono-ethnic groups and cross-cultural aspect of interpersonal relationships in the workplace in the period of reorganization.

Full name: Roman Osin

Institutional affiliation: Penza State University

Institutional address: Krasnaya Street, 40, Penza, 440026, Russia

Short biographical sketch: Ph.D., Associate Professor of the Department of General Psychology. In 2015, Osin R. defended his thesis on the topic "Features of the attitude to the image of a labor migrant under the conditions of media exposure by representatives of various socio-demographic groups" in the dissertation council on the basis of Kursk State University. Research interests: image psychology, media psychology, history of psychology, social psychology, psychology of sexuality, ethnopsychology. 